\title{
THE DEPICTION OF WAR IN LITERATURE FOR CHILDREN. AN APPROACH TO THE TOPIC
}

\author{
INÉS CONDOY FRANCO \\ Universidad de Alcalá \\ inescf95@hotmail.com \\ ORCID: 0000-0002-6801-8747
}

\section{ABSTRACT}

Last great-armed conflicts resulted in literary reactions, and after World War II it was a huge production of children's literature in order to approach the issue to young readers and help them to understand what happened. It can be considered the prelude of the recent politicization and introduction of different conflicts that children's literature is nowadays experiencing. When Hitler Stole Pink Rabbit (Judith Kerr 1971), Carrie's War (Nina Bawden 1973) and Good Night Mister Tom (Michelle Magorian 1981) are part of these post-war publications and through their analysis, it is aimed to study how the historical circumstances of the World War II are approached to children. Addressing how their authors represent the conflict, the separation and the family relations that play a crucial role on these works and children literature in general. Analyzing how society of the time is portrayed trough different motifs as the journey, the female figures or the war itself. The techniques they use and how do they overcome a common conflict of displacement, what can help young readers to learn strategies to face their own problems in real life.

KEYWORDS: children's literature, World War II, conflict, journey, displacement.

\section{INTRODUCTION}

Besides creating a realm of fantasy for the reader, children's literature helps the child to develop in aspects such as the acquisition of language, critical thinking, history and their own knowledge. This paper will deal with three works of children's literature, which belong to post-war English literature, a period characterized by the beginning of the intensive commercialization of books, the

expansion of literary criticism, [...] the popularization of audio-visual narrative media and [...] the growth of English Literature written by women and by post-colonial writers (Alegre 2011: 9).

The novels this paper will concentrate on have all been written by women and were very well received by the readership. The first novel is the renowned When Hitler Stole Pink Rabbit (Judith Kerr 1971), in which the author retells her childhood memories through the narrator Anna, a German Jewish girl who has to flee with her family because her father is a writer affected by censorship and harassed by Nazi power. Carrie's War was written by Nina Bawden in 1973 and it is also a fictionalized autobiography in which the author also revisits her childhood memories as inspiration to write the story of Carrie, who was sent from 
London to the countryside with her brother for safety because of air raids and, when she returns with her own children, she is confronted by her childhood memories. The third book is by Michelle Magorian, Good Night Mister Tom (1981) a story without autobiographical elements. The author tells the story of Willie Beech, a child who moves from London to the countryside and meets Mister Tom, a person who completely changes his world.

These works portray literature within the same culture, if these books were given to children in another context which are not the consequences of World War II and Western reality, their reading would change. These stories will surely still be useful and attractive for young readers, but they would be interpreted in a different manner and their impact on them would also differ. As Iyabide Omolara Akewo Daniel portraits in his work about literature in African culture, Western literature is also normally read in Africa, even if its interpretation changes.

Wisdom demands that the African makes use of what is Western in source to their advantage. How does this apply to the discussion at hand? Very simple. The African can adapt the Western to bow to the dictates of the culture it has come to colonise. (Daniel 2015: 150)

Using literature in this way, we are helping those children to overcome the conflict. They can also use strategies and resources found in the novels, beacuse reading does not just entertain, it also serves as an ideological tool:

It [ideology] is also built into the language we speak so that in order to participate in society we always and inevitably start by understanding ourselves as subjects within it. Because we internalize its views and value systems it is hard not to see them as natural, or even harder to change them. [...] The attitudes and positions proffered in the literature produced for young readers tell us a great deal about the preoccupations and values of the time. (Reynolds 1994: 5)

This is even more enriching, when readers are still learning, as it is the case with children. Reynolds is not the only author who supports this fact, it is a function of literature that has been deeply studied and other authors, as Silva, mentions "[c]hildren's literature is a way of empathy in the midst of otherness among adults and children" (Silva 2014: 141). This paper will examine the representation of conflict in children's literature and the processes that characters experience to overcome difficult situations. As well, the paper will dwell upon narrative strategies and devices such as the motifs portrayed (war, the concept of journey, house descriptions or girl's attitudes and their social role), how the child-figure approaches fantasy, how children have a reduced vision of the world, and how they use artistic production. This paper will examine how all techniques are introduced in the narrations to create characters who learn and evolve as the story progresses. 
The evolution of characters in war narratives is partly achieved through aspects that will become the centre of children's lives; as concentrating on them will help to overcome displacement and its consequences. In other words, this paper will examine how the main characters, who are children, assimilate conflicts. Khan exposes different techniques and strategies that can facilitate this process of the development of an identity, which, according to his own terminology, we will name "protective factors" as: attachment relationships, the figure of guardians and the role of child care institutions and schools. Fantasy is another relevant device that helps children to overcome conflict, as can be seen in the Narnia books (Lewis 1950-1956) or in Peter Pan (Barrie 1911). In Narnia the main characters are also evacuees, and in both, children create a fictional world, that helps them to deal with problems and to which they have to renounce when they have already learnt enough and they grow up. In Narnia, it is significant that the youngest sister is the last to leave her fictional world, because she needs more time to complete this growing up process. All those strategies not always play the same role, and we will study those mitigation techniques in each of our case studies as

[w] are dealing with resilience processes through fiction that means that we cannot base our research on veridical facts and real data, but we want to study how this process shown trough fictional narrative works oriented to young readership. (Betancourt \& Khan 2008: 319)

Even though resilience is not the focus of the paper, this statement is applicable to Magorian's work, but only partly to Kerr and Bawden's, as they base their narration on their own memories, even if they have been fictionalized, and create works which are considered as semi-autobiographies. ${ }^{1}$

\section{THE WORKS AND THEIR AUTHORS}

All three works examined in this paper tell a story of displacement during World War II. They share another feature: all three have been written by women. Literature has discriminated women throughout history, as testimony of this historical past Virginia Woolf wrote her famous novel A room of one's own (1929). However, there are also recent examples of this phenomenon. A contemporary example is Joanne Rowling, more known as J. K. Rowling, who decided to use this name format in order to try to skip the discrimination that still exists against women in the publishing world. With regards to literature for children,

it has been argued that women found it easy to write for children, because women were used to being with children; particularly in their roles as mothers, governesses, Sundayschool teachers, and so on. Related to this body of opinion is the idea that women could write for children because intellectually and emotionally women were like children. (Reynolds 1994: 28) 
Which is one of the reasons why women - some of the most famous being Astrid Lindgren, Enid Blyton, Christine Nöstlinger or Elena Fortún- have usually written children's literature, because that genre was not banned for them. This paper does not deal specifically with this issue, nonetheless, considering all three novels have been written by women, it is relevant to understand the context for those female writers.

\subsection{Judith Kerr}

Judith Kerr was born in 1923 and she published When Hitler Stole Pink Rabbit, a semi-biographical work about her childhood, in 1971. The novel is the first volume of a trilogy, with Bombs on Aunt Dainty and A Small Person Far Away. This paper will only address the first part of the trilogy that depicts her flight with her family from Berlin in 1933. This journey takes the Kerrs to Switzerland, France and finally England. The beginning of the story coincides with the prelude of the election of Hitler the German "Führer". As she states in her epilogue to the novel, "Hitler hated the Jews in general, but he particularly hated my father because of his writings" (Kerr 2014: n. p.). Her father was Alfred Kerr, a renowned writer and intellectual of Jewish descent, who anticipated publicly Hitler's electoral victory and its consequences for Europe. Kerr herself has admitted that she wrote the book to try to explain to her own children "what it had reallyfelt like to be suddenly poor, to live in foreign countries, to go to strange schools and to learn a different language" (Kerr 2014: n.p.). However, one of those languages became her own and the one she chose to write. When she started to write, she had one limitation: she could not remember certain facts with precision as a long time had passed. For this reason,

I decided that all the important things must be true-the things that happened, how I felt about them, what we, our friends and the places we lived were like-but that I would fill the gaps with invented details. (Kerr 2014: n.p.)

Kerr, gives the voice to Anna, a rather "small for her age" (Kerr 2008: 1) and clever girl, who always excelled in class due to her essays and compositions. In fact, writing and school would become the centre of her world and would help her to overcomedifficulties. The figure of the guardian is represented in both of her parents, although herbiggest influence and support comes from her father. Friends are also important to her, and it seems significant that in each of the places where she lives, she has a "best friend". Her older brother Max, always gives a great support as well.

\subsection{Nina Bawden}

The author of Carrie's War is Nina Bawden. Born in 1925, she was also an evacuee from the war. In her case, she did not flee with all her family as Judith Kerr, but 
she moved to the countryside from London to avoid the air raids. Even though her novel is also semi-autobiographical, it differs from Kerr's because she uses her life as inspiration, while Kerr directly tells her own (even if spiced up) experiences. Bawden, on the other hand, does not intend to be loyal to the order of events or to create her childhood story in an accurate way; this is why it is possible to find aspects of her life associated to different characters in her fiction. Carrie is the main character in Bawden's novel, and she and her brother Nick are also evacuees. They arrive to a mining village where they live with the Evans, two siblingswho host them. Carrie, a small girl with eyes "like emeralds" (Bawden 2014: 99), presents a very complicated internal conflict. On the one hand, she finds a real guardian that influences and guides her, and on the other, she feels she must be her brother's guardian as their parents are absent. The fictional world for her is linked with the Druid's Bottom (name the used for Hepzibah's house), Hepzibah's stories and the story of the skull.

\subsection{Michelle Magorian}

Michelle Magorian was born in 1947, and although she also has a displacement experience in her personal life (she and her family moved to Australia for two years), shedid not directly experience World War II and its consequences. Good Night Mister Tom is a novel, in which the author is not using personal memories or experiences of war, which is not to say that some of the struggles characters deal with have been inspired by personal memories. However, this often occurs in fiction, as authors reveal themselves in their texts in some way. The point is that this narration is the product of Michelle Magorian's imagination. It began as a short story and later Magorian realized she could continue and develop the story to write her first novel.

William, ${ }^{1}$ the main character in Magorian's work, is a child who lives with his mother in London and has to move to Little Weirdwold as an evacuee. He lives with Mr.Tom, a widower who takes care of him and represents a parental figure and a role model,something this child has never had. William's mother has not allowed him to be a child —not letting him play or get dirty with other children - and has deprived him of a proper education, which is the reason for William's physical and psychological weakness. He is seen as a "sissie" (Magorian 2014: 38) at school, with no friends and is malnourished.

Displacements to William happens to be a challenge and an opportunity to find a home. William has to overcome displacement and all the mistreatment he suffered from his mother. His friends, especially Zach with whom he develops a close relationship help him to do this. Mr Tom plays the role of guardian and

\footnotetext{
${ }^{1}$ In Good Night Mister Tom the main character, William Beech, is addressed as Willie or Will by his friends, especially Zach, depending on the different moments of the novel. All along the analysis it will be addressed as William, attempting to achieve a neutral tone. As the two different names refer to the character's evolution that will be later also discussed.
} 
teacher. At school he encourages William's artistic development in painting - something he is really talented at-, theatre and reading, which allows him to enter a fictional world where he can escape from reality.

\section{FEELING OF DISPLACEMENT}

The main objective of this analysis is to focus on how the feeling of displacement is portrayed through motifs and items associated with the child figure that can be found in these works.

\subsection{Representation of conflictive aspects in children's literature}

As it has been previously discussed, characters that face a situation of conflict, something unknown that results in changes to their social status, or other difficulties will often overcome them thanks to different sources of support. This point deals with how unknown places are represented in the three works, as well as how separation and attachment relationships are depicted.

\subsubsection{Conflict}

Children's literature about war is characterized by having a conflict as the focus and main thread of the story plot. In the three selected cases, this conflict is fueled by displacement, and how this situation affects the development of the character's personality. Displacement is described by the Cambridge Dictionary as "the situation in which people are forced to leave the place where they normally live". In those three novels, the journey the children experience is not just physical, psychological or social, but it has the three qualities at the same time. A change in location forces the evolution of the character's personality and likewise, it triggers changes in their social circumstance (whether this is to improve or toworsen it).

Canani names this displaced status as to be in absentia (Canani 2014: 35), as

[t]he status of Anna as both a child and a refugee, who is forced to leave her homeland, accrues her difficulty in defining her political status, and hence her identity. (Canani 2014: 35)

All the protagonists of the three works suffer displacement, but only Anna, the main character on Judith Kerr's novel, is a refugee who has to leave home to go to different countries where she has to adapt both to cultural and language barriers (Swiss dialect and French), presenting difficulties for her to adapt. In Magorian and Bawden's stories, children do not have to leave their country, "only" their homes, as they are evacuees, sent from the city to the countryside to avoid the danger of air-raids, and it's been proven through studies that "evacuation and the subsequent family separation caused more emotional strain 
than exposure to air raids" (Henshaw \& Howart 1941, quoted by Betancourt \& Khan 2008: 321). Hence, even though their circumstances are not identical the repercussions and the struggles these characters experience are similar. Canani also refersto Julia Hopes' words, "refugee children experience a sense of loss and trauma because they lack stability and security. As a result, they feel disoriented and bewildered" (Canani 2014: 39). Consequences that affect the main characters of these works use different devices in order to overcome them.

All three protagonists, Anna, Carrie and William, suffer a common conflict, namely forced displacement motivated by a war context. Nonetheless, each have different circumstances, and therefore they are affected by this struggle in different ways. A significant difference is apparent in When Hitler Stole Pink Rabbit, because although the three novels take place in the context of World War II, Kerr's work is set inthe years that preceded the war and focuses on Anna and her family escaping from Nazi Germany.

Anna suffers displacement not just once but several times, the first one when she and her family suddenly have to leave Berlin is the most traumatic for her. She does not understand what is happening and why someone would take her father's passport (which is the explanation her parents told her and her brother) or her own. She simply does not understand, but she obeys her mother when she tells them no to say a word "when the man comes to look at our passports" (Kerr 2008: 43). Consequently, it is not an easy situation to leave her house, her country and her Pink Rabbit behind. Once they are already in Switzerland and she has recovered from her illness they already know that Hitler has won the election and that they cannot return to Germany. What together with the news that Hitler put a prize on her father's head or that all his books were burnt (written by him not of his property, as she first understands) become totally unclear to her. Nevertheless, she has to face the challenge of a new school and a new language (or dialect), twice in these novels; aspects of which she will concentrate on and will allow her to overcome the other circumstances, that include a change of social position, as theyare suddenly "poor" and "needy" (Kerr 2008). This is demonstrated for instance when she writes about her father's trip for her certification test's composition and she is awarded a prize for this piece of writing. She suffers from it again when they have to move to France, and once more at the time of moving to England. Despite all these circumstances, as Kerr herself explains in the note of the author, everything was quite easy for her, because she was with her family as Anna also expresses, "I just think we should stay together" (Kerr 2008: 264). Indeed, at the end of the novel, she is quite happy as she had read that famous people had suffered a difficult childhood.

William Beech, is an abused child for whom, to become a refugee involves displacement and new situations but also a chance to live a better life. With this character, the subjectification process is more remarkable than in the other two stories. At the beginning of the story, William lacks any kind of confidence in himself, and has poor social skills, which is why he can be considered an anti- 
hero. For William, finding Mr. Tom represents a chance to access education and go to school. It allows him to discover his passion and talent for painting, which helps him to grow and develop his own character. Also, it gives him the opportunity to make friends that will also notice his evolution: "They all stared at him in surprise. It was unusual for him to volunteer withoutpersuasion" (Magorian 2014: 161). Once he has overcome that, he has to face his mother's suicide (which was not a real struggle for him as they were not really attached to each other, as she was not an especially loving mother with him), however he does not understand why she did it. Then, his best friend Zach, who dies in an air-raid. This was a real loss for him and he overcomes it when he understands that he must keep his memory "I'm not half a person any more, he thought. I'm a whole one. I can live without Zach though I still miss him" (Magorian 2014: 346). This process is the most difficult and painful one, but he counts with shared experience of his painting teacher (who was a Dunkirk survivor) and who gave him good advice "Better to accept, than pretend that he never existed" (Magorian 2014: 335) and the personal challenge to learn how to ride a bike. Therefore, for him displacement also brings loss, and he also experiences this displacement more than once, as Anna. The first is the evacuation, which has mainly a good outcome for him, even if at the beginning he is also bewildered by this event. But when he had already adapted to his new situation, he had to go back to his mother in London; this represents a greater displacement struggle for him, as well as a regression on his personal development.

Carrie is also an evacuee as a consequence of the war. Her father is a Captain in the military and it was too dangerous for their mother to move with her children. For her the real struggle is not really being in a strange place, but losing her mother, and she states: "Thinking of her mother, always making the best things [...] Carrie nearly cried"(Bawden 2014: 16). Therefore, for her the greatest consequence of war and displacement does not have anything to do with leaving her house or London, where she used to live, but she feels out of place, because she has lost her reference and one of her most important supports of her life, her mother. That is why, she does not mind moving back to Glasgow (which could represent displacement again), even if she is leaving her friends, because moving back to her mother makes her feel complete again.

\subsubsection{Separation and attachment relations}

The previous point describes how children face losses resulting from displacement, and the role of the family and other attachment relationships they develop. In all three novels, we can find characters that complement the main characters, regarding their personality and who also provide them with the information they need to cope in the world. 
Anna, as it has already been mentioned in Kerr's author's note, does not experience a real traumatic experience, because she was with her family and she does not lose her parents, her role models: "She and Max and Mama and Papa had nearly always been together. As long as they were together she could never have a difficult childhood"(Kerr 2008: 281). To Anna her father represents her biggest support and influence in her life. Anna admires her father, it is apparent throughout the novel and Anna even says once "Papa was too polite to stop him" (Kerr 2008: 89). The character who better complements her is her brother Max. In this case, Max is the older brother and has a deeper knowledge of the world in general. He is as illustrated as more introverted than Anna, interested in fishing by himself despite never catching a fish. He is less enthusiastic about school than Anna, as he usually shows no interest in it until they were in France "Max had become much more conscientious about school" (Kerr 2008: 202), and what probably seems the most important characteristic in contrast with his sister is that he worries much less than her about all the events they are experiencing.

Carrie is facing an internal conflict, motivated by displacement and the loss of her strongest influence and support, her mother, which is why she feels obliged to assume her mother's role to look after her brother even though she is not ready for this responsibility. As a result, she remains lost and though other characters help her, she does not find anyone to identify with and meet her needs. "Carrie looked at Nick on Hepzibah'slap and felt jealous. [...] And to Hepzibah, because she was comforting Nick in a way she knew she could never do" (Bawden 2014: 76). Her brother Nick represents the securityand social abilities that Carrie is missing and he develops a close attachment relationship with Auntie Lou and Hepzibah (as adult characters) and with Mr. John (as a more childish figure). Albert Sandwich is another important character that broadens Carrie's knowledge and opinion of the world. He may be described as a bit cynical but a really educated and mature boy, as he expresses his opinion about his name " I don't care for my name to be abbreviated', he said. 'Nor do I like being called Jam, or Jelly, or even Peanut Butter'” (Bawden 2014: 19) but still they differ on many topics as in the concept of friendship, "'I don't see what difference it makes, people's ages,' [...] 'People are either your friends or they aren' $t^{\prime \prime \prime}$ (Bawden 2014: 97). Albert seems to be more mature than other children. Regarding adults, Carrie receives a lot of support from Hepzibah, even though she doesn't fully understand her, and she is also confused about what to think of Mister Evans. She knows he is unfair but she also recognizes that he has a kind side. She feels sorry for him, but he confuses her and makes her unsure of how to behave.

For William as it has been described, displacement was more an opportunity than a challenge. Thanks to these circumstances he has the opportunity to find Mr. Tom who becomes a father-figure to him. He experiences separation when he has to leave him to go back to London, and misses him and his life in Little Weirwold. The second importantloss he experienced was his 
friends Zach's death. Zach could be described as the complementary character of William, his counterpart. In relation to their education, Zach has grown up surrounded by culture, theatre and writers as he says, "I was practically born in the theatre. I was breast-fed in theatre dressing-rooms" (Magorian 2014: 136) while William has been denied any access to culture or books other than the Bible. Moreover, Zack uses cultivated vocabulary that he usually explains to William and the other children. It is Zack and Mr. Tom (and his dog), that provide adult role models and allow William's evolution from being almost an anti-hero - due to his life's background,(as he had not developed almost any social skills) — to someone with his own opinions and developed critical thinking.

\subsection{Motifs}

These three works include several motifs which are important for the narration and the development of the conflict. Some are common to the three, such as the representations and allusions to war, the descriptions of the journey and of the houses, and the depiction of (forward-looking) progressive attitude of female characters.

\subsubsection{War}

War World II is the direct cause of displacement in these books, and in all of them, there are several references to it. This war provides the setting for all the works, but still very different representations of it are to be seen.

Anna is a refugee, who has to flee as a consequence of the pre-war, when the election of Hitler takes place and she lives in Germany, Switzerland and France. In her case, most of the references that will be noted affect her and her family directly and most of those remarks are about concepts that she does not understand, such as the game Nazis against Sozis:

'Nazis are the people who are going to vote for Hitler in the elections. We Sozis are the people who are going to vote against.'

'But none of you are allowed to vote,' said Anna. 'You are too young.' 'Our fathers, then, ' (Kerr 2008: 8)

The first description of Hitler where Anna confuses him with Chaplin or when they describe the swastika and add: "'It's a swastika,' said Gunther, 'All the Nazis have them'" (Kerr 2008: 8) and in fact, they did not know what to do with it. All these aspects are quite significant, as it is showing children's vision about the origin of theconflict. Anna does not know either what to be a refugee means:

'Is a refugee someone who's had to leave their home?', asked Anna. 'Someone who seeks refuge in another country', said Papa.

'I don't think I'm quite used to being one yet', said Anna. (Kerr 2008: 91) 
In Anna's case it is usually her father that comforts her the most, and who helps her to understand concepts that are completely new to her. He also explains to her what to be Jewish meant during those days and why they should demonstrate they were not only good, but also better than others (Kerr 2008: 121). Anna also refers to concentration camps, "Concentration camp? Then Anna remembered that it was a special prison for people who were against Hitler" (Kerr 2008: 115) and how Nazi's discrimination affected her and her brother directly as children, and they noticed, when the German children were not allowed to play with them because they were Jewish.

Carrie and William are living in England and are evacuees in their own country in order to be protected from the air raids of the cities. The events of war affect them in a less direct way. The idea of evacuation is clearly represented in Carrie's War which is described by Carrie when her mother tries to be optimistic about their circumstances.

As if Hitler had arranged this old war for their benefit, just so that Carrie and Nick could besent away in a train with gas masks slung over their shoulders and their names on cards round their necks. (Bawden 2014: 17)

Together with this explanation, there is also one of the few references to Hitler that can be found (on) in the work. Another example is to be found -addressing to the American soldiers - when they refer to Auntie Lou's boyfriend "it's a good thing the Americans have come, isn't it? To help us fight Hitler?" (Bawden 2014: 116). Apart from that, there is one more reference to food rationing, when mum goes to visit them and Mr. Evans tells her that as he has a groceriesshop the children won't notice it "They eat like troopers, you don't have to worry. Not that we have more than our ration, you know, in spite of the shop!" (Bawden 2014: 46)and a reference to air raids. When they know they will move to Glasgow with the parents Nick is wondering how it would be:

'Will we be bombed in Glasgow? Will the train be bombed on the way?' ‘[...] Don't be scared anyway. I'll be with you.'

'I'm not scared, I'd like to be boombed, it'ud be super exciting!' He started to sing again.

'Bomb, bomb, bang, shee-ow, ack, ack, ack...' (Bawden 2014: 176-177)

And this is like a game for him, as they have not really had to experience the real consequences of the war thanks to the evacuation.

In Magorian's novel, we find several references to the context of war, the first of them also address the evacuation, and the volunteer help, as people of Little Weirwold were organizing themselves to provide assistance when William first arrived. As well, asnumerous descriptions of people holding gas-masks "An hour later the twins and Georgewere waiting on the corner with their baskets, bags and gas-masks" (Magorian 2014: 101) or the construction of an air raid shelter for the Doctor (a Mister's Tom friend) and his family. There are also some 
references to poverty and how as time passes (with the passing of time) the situation and food rationing became more and more complicated at ageneral level, although William and Tom are not directly affected by that. However, "Tom and Will decided to make toys for those that had lost one or both their parents and for the many that were so poor that they wouldn't have presents anyway" (Magorian 2014: 331). Several allusions are also made to big events of the war, such as the invasionof Poland (Magorian 2014: 52) and Finland, and one of the biggest bombings of Munich (Magorian 2014: 166-1667), or to Dunkirk (Magorian 2014: 279) and Winston Churchill (Magorian 2014: 310). Most of them work as temporal guideline to the narration but they do not affect him directly, just when his friend Zach is worried because he could not contact his parents. Mr. Tom also experiences an air raid directly in London, and it also reassures the reader about how safe it was to live in the country in comparison to big cities

[s]uddenly a loud siren wailed across the sky. [...] He had readabout communal shelters in the newspapers and he knew that people often crowded into the tubes but he had no idea where the nearest tube station was. (Magorian 2014: 232)

\subsubsection{Journey}

The idea of journey is also remarkable in these books, as it provides one of the clearest descriptions of how children feel about the situation of moving away from home compelled by the circumstances of war. This motif commonly associated with train journeys and it is especially relevant for Anna and Carrie.

In When Hitler Stole Pink Rabbit we witness train journeys of Anna and her family escaping from Nazi's prosecution, which shows quite two different approaches that change as the child understands more about their situation. In the first trip from Berlin to Zurich, the siblings travel with their mother in order to reunite with their father who has gone ahead of them. During this journey, Anna notices her mother's nervousness:

The corners of her mouth were pulled down and at the bald man opposite without seeing him at all. On her lap was her big handbag [...] She was holding it very tight- Anna supposed because the tickets and passports were in it. (Kerr 2008: 37)

This description transmits clearly the stress of the situation and Anna's confusion. She is totally relieved when they finally reunite with her father, and it is he who expresses his fears "'I couldn't see you,'said Papa. 'I was afraid...'” (Kerr 2008: 49). The second trip is from Zurich to France. It is again quite a stressful situation, but the main difference to be seen in Anna is that she is already aware that they cannot return to Germany, as she is the one that realizes, they were almost going to catch the wrong train "It read STUTTGART. 'Papa!' screamed Anna. 'This is the wrong train! It's going to Germany!'” (Kerr 2008: 135). There is a third trip when they finally move to London where something seems familiar to her: 
There was something familiar about the situation - her tiredness, the sound of the train wheels, and the rain spattering on the windows. It had all happened before, some time long ago. (Kerr 2008: 277)

Anna finally understands the situation and the journey becomes "normal" to her. In all three journeys Anna notices that they are in a foreign place because she listens to different accents or languages:

Anna had already sensed something different in the train after leaving Basle. There had been more French voices talking quickly, sharply and incomprehensibly. The smells from the dinning-car had beendifferent too. (Kerr 2008: 137)

For Carrie, the train signifies the beginning and the end of her conflict. It marks the separation from her mother, and it has already been commented on how she feels when she and her brother have to leave their mother. How all of a sudden, she feels the burden of taking care of her brother as well as going to an unknown place, as Carrie later explains to her own children: "There were whole train-loads of children sent away like that..." (Bawden 2014: 2) and how difficult was to be a little child as they were, and to have to leave on their own. As well as the train to come back with her mother, it meant the most traumatic of this period of her life, as shows her denial to mention the place where she was taken: "Carrie never mentioned Druid's Bottom after that day" (Bawden 2014: 199). She feels that it is her fault that Druid's Bottom is burning: "She said between sobs that seemed to tear her chest open, something that sounded like, 'All my fault...'" (Bawden 2014: 198-199), she broke the skull and the curse fell over her friends, she never overcame this trauma. The fact that she returned as an adult indicates her acceptance of the situation. However, she never found out if her friends survived the fire or not.

In Good Night Mister Tom, the train journey is not as significant as in the other two novels. There is no reference to it or to any goodbye to William's mother before the evacuation. Instead, the important trip by train happens when he comes back to supposedly to visit his mother (even if she pretended that he stayed with her). The conversation he has on the train shows his new confidence and evolution:

'I draw, like'

'Oh,' he said, and he saw be the sudden brightness in Willie's eyes and his smile that this would be a good subject to talk about.

'You have any on you then?' 'Yeh'

'Ah'd like to see them if, that is, you're willing.'

Willie nodded shyly and opened his rucksack. (Magorian 2014: 206)

This trip will make him realize that he does not really remember his mother "Willie was puzzled. What was she like? At the moment she was just a dim 
memory. Shehas dark hair. He remembered that much." (Magorian 2014: 205) and that she had alsoforgotten him:

'Mum' he cried, 'Mum!'

'Go away,' she said sternly, 'You won't get no money from me.' (Magorian 2014: 210)

As she shouts before recognizing him. This trip is also the greatest depiction of what was it was like to live during the war and air raids; and how William's life was before he moved to Little Weirwold with Mr. Tom, who finally rescued him and brought him home again by train.

\subsubsection{Houses}

The descriptions of houses are another way of showing children's real vision of this period of time, and of their personal circumstances. They often play a central part of their worlds, combined with the diverse relationships with family and friends they develop. Therefore, as displacement involves a change of house it also serves as a direct reflection of their feelings and impressions.

Anna is the one that has to change from one place to another most often and the significance of that, is that she gives detailed descriptions of the two places she would call "home". She comments on the Zwirn's

Mama and Papa shared one room and Anna and Max another [...] Downstairs was a large comfortable dining room decorated with deers' antlers and bits of edelweiss. (Kerr 2008: 65)

and about Zurich's hotel (we just know she was sharing a room with Max), but she also provides details about her homes in Berlin and Paris, which indicates that they were of great importance to her bearing in mind that Kerr is writing from her childhood memories.

There is also a reference to the empty rooms and to the different parts of the house while Max says farewell to all of them: "They started at the top and worked down. Most of it no longer looked like itself" (Kerr 2008: 34). She begins the description with their room and continues with the rest of the house:

Their room was painted in a rather ugly yellow and there were yellow bedspreads on the two beds. A wooden wardrobe stood in the corner. (Kerr 2008: 141)

Carrie and William also describe their new places, and for them the differences from their first places to the next one are more striking due to the fact that they were living with strangers. For Carrie the rules about the house were more shocking than the house itself (it was more shocking than the house itself the rules about it) especially regardingthe stairs "She thought she would never dare touch anything in this house in case she left marks. She wouldn't dare breathe - even her breath might be dirty!" (Bawden 2014: 25), and the toilet, they had to 
go outside during daytime and this was especially shocking for Nick "'Spiders.' Nick's eyes rounded with horror" (Bawden 2014: 29). While for William everything is new, he even has his own room, something he has neverhad while living with his mum, as he retells during the time, he spends there during his short trip back to London

Opening his eyes he looked around in the darkness. He knew immediately where he was. He had been locked under the stairs. [...] The night before hehad been lying in his first and only bed, in his and only his room. (Magorian 2014: 223)

a description that reinforces the changes in Williams's life since his evacuation.

\subsubsection{Representation of young female figures}

In two of the novels the main character is a young girl and both of them are very combative against social injustices.

Judith's Kerr alter ego in When Hitler Stole Pink Rabbit, Anna, shows it in very different ways. Anna does not have to face these kinds of struggles or discrimination at home, as her parents make no distinction between their children. Moreover, her father encourages her the most to write and to write in her own style. Despite that, Anna will realize about the inequality that existed within her family

\footnotetext{
Anna and Max helped by doing odd jobs like shopping and emptying the dustbin, but of course most of the work fell back on Mama and she grumbled about it incessantly.

'I don't mind cooking,' she said, 'but it's the endless washing and ironing and mending

- it takes so long and it goes on forever!'

Papa was no help at all. He had no idea what needed to be done in a household and when Mama complained how tired she got ironing the sheets he seemed genuinely astonished.

'But why do you bother?' he asked. 'They get crumpled again anyway when people sleep in them.'

'Oh, you don't understand anything!' cried Mama. (Kerr 2008: 232-233)
}

This fragment does not mean that Anna's father was a bad person, but it is simply portraying the social reality; the fact that Anna realizes it is significant and it reflects how social change had already begun when Kerr wrote the novel. It was probably also influenced by her adult vision of the issue. Linked with the assumption that women should be solely responsible for housework, we notice the difference between having a housekeeper or not, and the fact that sewing was a subject in Anna's school in Paris. Indeed, it was the only subject she failed on the certification exam: “'You've done it! You've done it!' she cried. 'You've got distinctions in gym, so now it won't matter if you've failed in sewing!' (Kerr 2014: 252) Something that astonished her and her mum, but the important matter here is how she is going totally against the trend, a nod to women's 
independence. She experienced a similar situation in the Swiss school, where it was the first time she saw gender separations in class and in games. One day, she decided to play with boys, something that shocked everybody and resulted in all the boys falling in love with her. Love that they showed as they had been taught: 'It's what they do here,' [...] 'When they' re in love with anyone they throw things at them' (Kerr 2014: 85). Although this is just an anecdote, and seems a little primitive, Anna's and her mother's reaction highlights the cultural differences between Switzerland and Germany about the issue.

Carrie's character is remarkably less combative than Anna's, but still in Carrie'swar there are some elements that portray the social context. A positive one is the fact that their mum was driving an ambulance in Glasgow as a volunteer during the war and her uncharacteristic short haircut. When Carrie expressed her feelings about it, she says she does not like it, but there is a huge message on these two actions. The second element, we observe is the relationship between the Evans siblings, where Mr. Evans has (a) complete authority and control over his sister. It can be seen when Ms. Evans, "she wentto stay with a friend in the bigger town down the valley. She stayed for four days and Carrie did the cooking at home" (Bawden 2014: 95). At no point is questioned if this is an appropriate task for a twelve-year old girl as it was the social reality of the time. This context is also shown with Mr. Evans' opinion about lipstick and colourful clothes: "Girls who wore lipstick and silly clothes and went out with American soldiers were good as damned in his opinion" (Bawden 2014: 113). A judgement that the children believe to be oppressive and unfair.

In Good Night Mister Tom, the main character is not a girl, but still there are a lot of references to this topic. The first one and which has a great importance, is the figure of Mister Tom, as widower, who is in charge of housework, and he takes cares of the child. We can suppose that this is not only a break with social traditions, but also a message of how society is mistaken regarding this issue. In this novel, we are also told of William's reaction to a woman driving a bus when we come back to London: "It was the first woman Willie had ever see working on a bus" (Magorian 2014: 216). That may be seen as one of the impacts of the war that the twins (the two girlfriends of William) have already mentioned when they were discussing girls' chances vs boys':

'Ent it a blimmin' cheek,' she exclaimed angrily. 'Boys gits all the chances. The grammar school in Weirwold only takes boys', she said in protest to Zach, 'and they never bother to put girls in fer the high school. And here's me dying to go and him' waving a finger at George, 'having all the chances, and him hating books.'

'Mebbe now there's a war on', said Ginnie, gently touching her sister's arm, 'it'll be different for girls.' She knew how much learning meant to her. (Magorian 1973: 250)

Carrie finally managed to go High School with encouragement form Zach and her father. At home her mother was reticent about girls being educated and often tried to give her extra housework because she thought that books were a 
waste of time. In contrast, her father, "Secretly he was rather proud that one of his daughters wanted to take it. The war was encouraging to be more independent now" (Magorian 2014: 200). This portrays a positive message to the reader.

\section{REPRESENTATIONS OF CHILDREN FIGURES}

Representations of children in the studied novels can be seen through the devices of: fantasy, a reduced vision of the world and the use of artistic production as a shelter. These devices feature in these stories and in the characterization of the children in general, therefore the role of these three aspects will be examined in the three texts.

\subsection{Fantasy}

Fantasy is normally associated with children and undoubtedly children are those with the greatest imagination and who can best experience fantasy and the worlds derived from it. It also helps children to escape from a difficult reality. In these novels we can clearly see the existence of a fantastic world in Magorian's and Bawden's novels. In the case of Kerr, it would be more accurate to say that Anna's imagination plays an important role, because she is experiencing reality the whole time but in her thoughts/in her imagination she imagines Hitler playing with her Pink Rabbit. She also misunderstands the expression "to put prize on someone's head" and shows that she also possesses the skill of escaping in to a fantasy world.

'Don't you know what is meant by a price on someone's head?' ‘Not... not what I thought?' said Anna.

'No', said Max. 'Not at all what you thought. Putting a price on a person's head means offering a reward to anyone who captures that person.' (Kerr 2008: 130)

William's fantasy world is linked to theatre where he can express what he is imagining: "All he' d done was to make a picture of someone in his head and worm his way inside it" (Magorian 2014: 173). Something that comes with the belief that Spooky Cot was haunted, and the feeling of adventure when they decide to explore it, that will let him forget about problems and real life. The same feeling that Carrie experiences at the Druid's Bottom where Hepzibah who is supposed to be a witch

'She is a witch', he said calmly. 'A witch?'

He grinned at her. 'Oh, not what you're thinking of. Not black cats and brommsticks! Just what country people call a wise woman. (Bawden 2014: 67)

Hepzibah tells them stories such as the one about the skull of the black child, according to which "they'd broken a promise. So he put a curse on the house" 
(Bawden 2014: 74). She really believed this story and it also made her forget about the life at the Evanses, which she did not really like.

\subsection{Reduced vision of the world}

In children's literature a reduced vision of the world, is often presented which coincides with the focus on the action, the reduced number of descriptions and a story without almost any interruptions in the time line. These features make reading easier and help the characters to overcome difficult situations, they focus on a specific aspect of their lives, things that are part of everyday reality on which they concentrate in order to be able to continue despite adversity.

The first evidence of the world being reduced for Anna and her brother comes when they are packing before leaving for Switzerland. Anna's most difficult decision is what toy to include, and the fact that she loses her Pink Rabbit becomes one of the most important aspects of the novel. Up to the point that this little toy gives title to the novel and she even remembers it once they are in France and almost two years later: "I expect Hitler plays with it now" (Kerr 2008: 203). Even when they move to places where they effectively live, Switzerland, Paris and Berlin, their lives are focused on two main environments: home and school. Between, these the greater importance is on school: "She was, in any case, much too interested in school to pay much attention to what was happening at home" (Kerr 2008: 248).

For William, we may say it was the opposite; the two most significant environments are also the familiar one, which includes both Tom and his friends, and school. Something completely new for William as we notice in the celebration of his birthday party "Willie was completely overcome. He sat down and stared at the gifts speechless" (Magorian 2014: 123). In William's story, even if school represents an important aspect of his world, it changes with the evolution of the story and his character, losing importance that is replaced by his friends and playing, that provides him with nicer side of reality -a development that will be interrupted by the travel to London to visit his mother.

For Carrie, in contrast with the other two stories, school does not play an important role. In fact, it is just vaguely mentioned at the beginning of the story when Carrie indicates to her children "there wasn't room for us all in the school" (Bawden 2014: 13) and when she remarks how different it was from her school in London "It was quite different from going to school in London. More fun, Carrie thought" (Bawden 2014: 43). There are also two main different environments, the Evan's house and the Druid's Bottom which becomes the most important place where the children feel most comfortable, and may be taken as a fictional world inspired by Hepzibah stories. Carrie and her brother don't show any signs of remembering London where they used to live before the evacuation. 


\subsection{Artistic production as a shelter}

Artistic production is a device commonly used to overcome difficult situations, both for adults and children. There are numerous artists that have created masterpieces in order to escape from difficult experiences they have suffered, for example El Guernica by Picasso. Writers have often said they get more inspiration from unhappy periods in their lives, and it is for this reason that so much poetry is devoted to love and suffering... In Kerr's and Magorian's works we can also find this device is used. In Anna's case writing helps her, perhaps inspired by her father who is also writer, and who encourages her the most to keep writing whatever she likes:

'My teacher Fraülein Schmidt thinks I should write about more cheerful subjects like the spring and the flowers.'

'And do you want to write about the spring and the flowers?'

'No', said Anna sadly. 'Right now all I seem to be able to do is disasters.' (Kerr 2008: 13)

In her case it is also possible to observe how writing helps the main character Anna in the novel to express what she has experienced to gain confidence in herself and to develop a strong character. She decided to write about her dad's first trip to leave Germany for her French Studies Certification test composition:

Anna decided to describe what she imagined Papa's journey must have been like from Berlin to Prague with a high temperature, not knowing whether or not he would be stopped at the frontier. (Kerr 2008: 250)

for which she was awarded a prize by the Mayor of Paris about which her father said "[i]t's your first professional fee as a writer" (Kerr 2008: 254).

Drawing helps William to develop as a person. Everybody around him remarks on his talent, even the painter that was living in Spooky Cott and that offered to give him some lessons told him "[y]ou have a gift, Will" (Magorian 2014: 312) and the soldier he meets on the train back to London "' [o]ch,' he cried in surprise, 'ye can really draw. Och, these are guid, these are really guid" (Magorian 2014: 206). His drawing skills help him to feel part of a group with his friends, for example when they decide to create their Gazette, he is in charge of illustrations. Theatre also helps him to develop his creativity. It changes his ideas about theatre and helps him to forget about anything else during this time. It helped him to develop his identity, nevertheless, it was not enough to overcome his grief after Zach's death, "[e]ven in drawing and painting classes he would sit and look blankly at the empty page in front of him, devoid of ideas" (Magorian 2014: 330) and it shows that in William's case he needs to feel happy in order to be inspired. 


\section{CONCLUSION}

World War II is a topic that has been depicted in diverse ways in the History of the arts: film, art, literature, and music. The historically tainted depictions of war have always aroused interest: particularly because not so long ago survivors were still alive and because of the brutal events that preceded the conflict itself. Children's literature has also played a role in introducing youngsters to History and many narratives have pivoted around the topic of WWII. This analysis has focused on the topic, examining it from the point of view of the child. As already illustrated through these examples of children's literature, we are presented with the children's vision of the conflict, and in some of the works, as in Judith Kerr and Nina Bawden's, the story is inspired by the author's personal experiences. In some cases, they even retell the author's life as in When Hitler Stole Pink Rabbit, but they always add fictional elements, as Mario Vargas Llosa remembered Valle Inclán's thought: «Las cosas no son como las vemos sino como las recordamos» (Vargas Llosa 1990: 8).

This paper has examined how children's literature in general, and these three books in particular, provide young readers with examples and techniques that may help them to learn and to overcome struggles in their personal lives. The main theme in the stories is displacement; something that nowadays can also occur for different reasons. These kinds of literary works not only help children to understand historical events and prepare them to face problems as they grow up, but they also teach them to empathize with other people that may be suffering around them. They are works not only of interest to children, but also to adults as they can be used as a tool to help adults to understand the child's way of thinking and to understand difficulties, especially when works are based on autobiographical experiences.

Through the selected studied works, it is not only possible to approach displacement and its main causes during the time of WWII and for it, and its consequences in different countries as England (in Magorian's and Bawden's novels) and Germany, Switzerland or France (according Kerr's narration) may be. In the present historical context, it is still possible to find displaced children for various reasons as the armed conflict in Syria or other conflicts, or Trump's migratory policies. These books, also offer some strategies and devices that assist the affected children to overcome difficult situations such as the creative production or the use of fiction as a shelter that lets them escape from their reality. The stories depicted in this paper, and many others may help children to face difficult situations such as divorce, the illness of a close relative, or any other unfamiliar and difficult circumstances and use some of these strategies in real life situations. 


\section{BIBLIOGRAPHY}

Alegre MARTín, S. (2011), “Post-War English Literature 1945-1990” [online]. Barcelona: FUOC, n.d. [Access date: 16/04/2018]. Available at: $<$ https://www.davuniversity.org/images/files/study-material/Post-War\%20Eng1 ish\%20Literature\%201945-1990.pdf>.

BAWDEN, N. (2014), Carrie's War, London, A Puffin Book.

BROWN, J. (2003), “'How the World Burns': Adults Writing War for Children”, Canadian Literature, 179, 39-54.

CANANI, M. (2014), “Displacement, Trauma, and Identity in Judith Kerr's When HitlerStole Pink Rabbit", Cultural Perspectives - Journal for Literary and British Cultural Studies in Romania, 19(1), 32-44.

DANIEL, I. O. A. (2015), "Children Literature: A Potent Tool in the Hands of Absentee Parent(s)", Advances in Language and Literary Studies, 6(1), 150-156.

FADIMAN, C. (2018), “Encyclopaedia Britannica” [online]. Britannica, 6/4/2018 [Access date: 6/4/2018]. Available at: <https://www.britannica.com/art/childrensliterature $>$.

GREGORY K. \& FRITZ, M. D. (2015), "Psychological resilience in children", The Brown University Child and Adolescent Behavior Letter, 31(2), 8.

HASSE, D. (2000), "Children, War, and the Imaginative Space of Fairy Tales", TheLion and The Unicorn, 24(3), 360-377.

HuNT, P. (2014), “Fiction Writing History: Truth, Illusion and Ideology in English Language Historical Fiction for Children", Cultural Perspectives, 19(1), 22-31.

HUNT, P. (1985), "Necessary misreadings: directions in narrative theory for children literature", Studies in the literary migration, 18(2), 107-112.

KERR, J. (2008), When Hitler Stole Pink Rabbit, London, Harper Collins.

BETANCOURT, T. S. \& KHAN, K. T. (2008), “The mental health of children affected by armed conflict: Protective processes and pathways to resilience", International Review of Psychiatry, 20(3), 317-328.

MAGORIAN, M. (2014), Good Night Mister Tom, London, A Puffin Book.

MCKenZIE, A. (2007), “The Children's Crusade: American Children Writing War”, The Lion and the Unicorn, 31(2), 87-102.

MeHMOOD, A. \& IQRA, J. (2014), “Children Literature: Shaping Gender Identities”, Asia Pacific Journal of Miltidiciplianary Research, 2(1), 240-242.

MULlAN, J. (2006), How novels work, New York, University Press Oxford.

NATOV, R. (1986), "The Truth of Ordinary Lives: Autobiographical Fiction for Children", Children's Literature in Education, 17(2), 112-125.

RAMírez ZuluaGA, L. A. (2015), “El sujeto en los jugos de poder: subjetivación y desubjetivación desde Faucault", Revista de Psicología, 7(2), 133-145.

REYNOLDS, K. (1994), Children's Literature in the 1890s and the 1990s, Plymouth, Northcole House in association with The British Council.

Do SiLVA WlLingtON, A. (2014), “Literature children-Child as protagonist”, Journal of humanity print, 2(1), 110-145.

SubTROvÁ, M. (2009), “When Children Die in War: Death in War Literature for Children and Youth", Bookbird: A journal of international children literature, 47(4), 1-8.

TOWNSEND, J. R. (1965), Written for children, Aylesbury, Penguin Books. 
VORACEK, J. et al. (1976), Give Children the Best: International Conference of Writers and Theoriticians of Literature for Children and Young People, Prague, Albatros. 